\title{
Lesser Pumpkin Fly, Ethiopian Fruit Fly, Cucurbit Fly, Dacus ciliatus (Loew) (Insecta: Diptera: Tephritidae) ${ }^{1}$
}

H. V. Weems, Jr. ${ }^{2}$

\section{Introduction}

The lesser pumpkin fly, Dacus ciliatus (Loew), is one of several fruit flies found in Africa and Asia which could be expected to become serious pests of Florida agricultural crops if introduced into this state. This species has not been intercepted in the United States, but prospects are likely for this to occur because of our heavy international traffic.

Throughout a large part of Africa and India this fruit fly is a common pest of cucurbits, although not as serious as the melon fly, Bactrocera curcurbitae Coquillett, in areas where both species occur. Heavy infestations of cucurbits by $D$. ciliatus have been reported in Egypt and in South Africa. Until recently, damage in some areas has been mistaken for the similar injury caused by a closely related species, Dacus longistylus Wiedemann.

D. ciliatus first was reported in India in 1914 and was collected first from Ombo, Upper-Egypt, in February 1953.

\section{Synonyms}

Dacus apoxanthus decolor Bezzi

Dacus brevistylus Bezzi

Dacus insistens Curran

Dacus sigmoides Coquillett

Didacus ciliatus (Loew)

Leptoxyda ciliata (Loew)

Tridacus mallyi Munro

Dacus sigmoides Coquillett

\section{Distribution}

D. ciliatus occurs throughout most of eastern, southern, and central Africa, Malagasy Republic (Madagascar), Mauritius and Reunion Islands, the Arabian Peninsula, Pakistan, India, Bangladesh and Sri Lanka (White and Elson-Harris 1994).

1. This document is EENY-258 (originally published as DPI Entomology Circular 81), one of a series of Featured Creatures from the Entomology and Nematology Department, Florida Cooperative Extension Service, Institute of Food and Agricultural Sciences, University of Florida. Published: January 2002. This document is also available on Featured Creatures Website at http://creatures.ifas.ufl.edu. Please visit the EDIS Website at http://edis.ifas.ufl.edu. Additional information on these organisms, including many color photographs, is available at the Entomology and Nematology Department website at http://entnemdept.ifas.ufl.edu/.

2. H.V. Weems, Jr., Florida Department of Agriculture and Consumer Services, Division of Plant Industry, Gainesville, FL>

The Institute of Food and Agricultural Sciences (IFAS) is an Equal Employment Opportunity - Affirmative Action Employer authorized to provide research, educational information and other services only to individuals and institutions that function without regard to race, creed, color, religion, age, disability, sex, sexual orientation, marital status, national origin, political opinions or affiliations. For information on obtaining other extension publications, contact your county Cooperative Extension Service office. Florida Cooperative Extension Service / Institute of Food and Agricultural Sciences / University of Florida / Larry R. Arrington, Interim Dean 


\section{Life History}

The complete life cycle typically requires 19 to 22 days as recorded under laboratory conditions at Coimbatore in Southern India. The egg stage lasts two to four days, the larval stage four to six days, the pupal stage eight to 10 days, and the preoviposition period at least four days. Three to four eggs usually are deposited in a single puncture made in the fruit by the ovipositor of the female fruit fly, but sometimes as many as eight eggs are deposited in a single hole, typically near the stalk. When 10 or more eggs are deposited in a single fruit, larvae usually do not obtain sufficient nourishment, resulting in undersized adults. Pupation takes place in the soil.

\section{Identification}

The egg is shiny white, about $2.5 \mathrm{~mm}$ long, slightly curved, cylindrical, and narrow at one end. The larva is pure glistening white, except as appearances are altered by the color of the food within the alimentary canal. The third-instar larva, which is of typical maggot appearance, is about $8 \mathrm{~mm}$ long and $1.4 \mathrm{~mm}$ wide. The mandibular hooks of the mouth parts are provided each with a preapical tooth and oral lobes, which are well developed; each has 15 laminated ridges. Each anterior spiracle bears 14 to 16 lobes. The puparium is elliptical, brownish, about 4.5 to $5.5 \mathrm{~mm}$ long and 2 to $2.5 \mathrm{~mm}$ wide.

The adult fly is 6 to $7 \mathrm{~mm}$ long, the body predominately dark fulvous yellowish-brown with pale yellowish markings on the thorax as viewed from above. Distinctive characteristics of the adult are the wing pattern, long third antennal segment, face with two large black spots and one brown spot on the peristome near the lower part of the eyes, and thorax with the scutum slightly darker than the rest of the body, with a median presutural line and two submedian postsutural black spots (very evident in alcoholic specimens, almost invisible in those preserved dry); humeral calli, suture, pleurae opposite the suture, hypopleural spot and the scutellum yellowish-white or ochraceous. Ovipositor of the female from above, $1.56 \mathrm{~mm}$ long, the tip without serration; many microspines form a band mid-length of the ovipositor sheath.

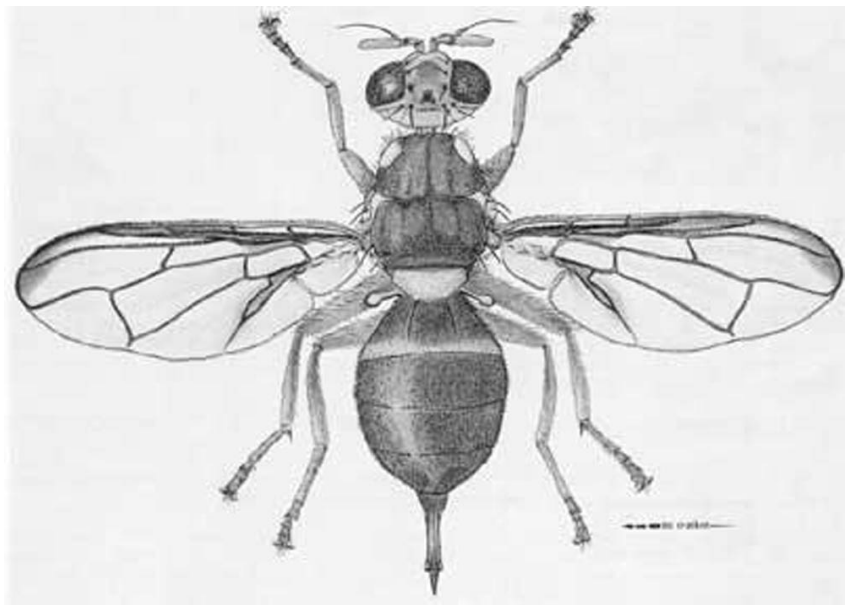

Figure 1. Adult female lesser pumpkin fly, Dacus ciliatus (Loew). Credits: Division of Plant Industry

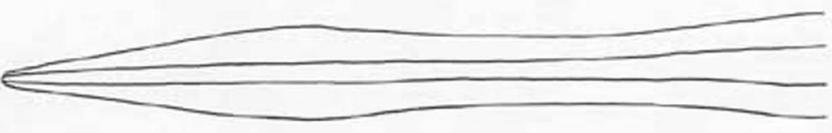

Figure 2. Ovipositor tip. Credits: Division of Plant Industry.

\section{Hosts}

Cucurbits are the principal hosts, with several other crops apparently of less importance. The lesser pumpkin fly has been recorded from balsampear, bean chayote, bluecrown passionflower, calabash gourd, citrus, common tomato, cucumber, Cucumis metuliferus, cushaw, edible snakegourd, Gliricidia sepium, gooseberrygourd, ivygourd, milkweed, Momordica involucrata, M. schimperiana, muskmelon, pumpkin, redpepper, Singkwa towelgourd, watermelon, winter squash, and yellowflowergourd.

\section{Attractants}

Not attracted to cue lure, methyl eugenol or vent lure (White and Elson-Harris 1994).

\section{Selected References}

Azab AK, Kira MT. 1954. Soc. Fouad I ${ }^{\text {ER }}$ d'Ent. Bull. 38: 379-382.

Bezzi M. 1915. Bulletin of Entomological Research 6: 85-101.

Cherian MC, Sundaram CV. 1939. Indian Journal of Agricultural Science 9: 127-131. 
USDA, Survey and Detection Operations, Plant Pest Control Division, Agr. Research Service.

Anonymous. 1960. Insects not known to occur in the United States. Cooperative Economic Insect Report 10: 35-36. Lesser pumpkin fly (Dacus ciliatus (Loew)).

White IM, Elson-Harris MM. 1994. Fruit Flies of Economic Significance: Their Identification and Bionomics. CAB International. Oxon, UK. 601 p.

White IM. (2000). Identification of peach fruit fly, Bactrocera zonata (Saunders), in the Eastern Mediterranean. The Natural History Museum. http://www.iaea.or.at/programmes/nafa/d4/public/ zonata.html (26 December 2001). 